\title{
Overview on pharmacovigilance of nephrotoxic herbal medicines used worldwide
}

\author{
Noufissa Touiti ${ }^{1,2 *}$, Tarik Sqalli Houssaini ${ }^{3}$ and Sanae Achour ${ }^{1,4,5}$
}

\section{Introduction}

There is a growing use of herbal medicines worldwide. Especially in patients with chronic diseases such as kidney disease, when numerous studies have shown a generalized high prevalence [1-4]. However, there are concerns about herbal medicines and their ability to produce harmful effects. Examples from the literature have clearly shown the association between the use of herbs and kidney disease $[5,6]$. The increasing use of herbal medicines has increased the need to monitor their safety. Thus, the approach recommended by the World Health Organization (WHO) was to include herbal medicines in existing national pharmacovigilance systems [5]. The pharmacovigilance of medicinal plants or phytovigilance involved the evaluation of the risks and benefits of phytotherapy. The ultimate goal is to protect patients from herbal harm [6] . It is essential to develop reliable information on the safety of herbal medicines [7]. Becoming necessary due to risks of toxicity (acute or chronic) or risks of drug interactions (of pharmacokinetic or pharmacodynamic nature), as regards interactions between several associated plants, phytovigilance also represents a legal obligation [8]. Several issues related to how herbal medicines are named, perceived, obtained and used [9]. At international level, the WHO published guidelines on pharmacovigilance of herbal medicines [10]. However it is still a new activity in the majority of countries of Africa. Except in Morocco where a pharmacovigilance program in phytotherapy was created in 2000 [6]. Also the creation of Botanicus and Phytotox

\footnotetext{
* Correspondence: noufissa.touiti@usmba.ac.ma

'Laboratory of Biomedical and Translational Research, Faculty of Medicine and Pharmacy of Fez, Sidi Mohammed Ben Abdellah University, Fez, Morocco

${ }^{2}$ Faculty of Science and Technology of Fes, Sidi Mohammed Ben Abdellah University, Fez, Morocco

Full list of author information is available at the end of the article
}

[11]. This situation requires knowledge, recognition and monitoring of adverse reactions through pharmacovigilance of herbal medicines activities [12, 13]. In order to show renal sides effects of herbal medicines use and current need to monitor phythovigilance worldwide, systematic research was carried out on PubMed, Science direct and Scopus. Moreover, some accessible databases on pharmacovigilance of herbal medicine or phytovigilance were consulted (Table 1). The aim of this article was to provide an overview of nephrotoxicity associated with the use of herbal medicines.

\section{Materials and methods}

\section{Search strategy}

Electronic literature searches were conducted in Mai 2020 to identify case reports of nephrotoxicity associated with herbal medicines use in the last two decade. The scientific resources including PubMed, Scopus, and Science direct were searched using key words such as: 'case report', 'Renal side effect', 'adverse effects', 'Nephrotoxicity', 'Risk', 'Herbal Medicine', 'kidney disease'. The spectrum of herbal induced kidney injuries included kidney stones, nephritis, nephrotic syndrome, necrosis, acute kidney injury, chronic kidney disease, and death. English articles were the primary focus, but some reports in other languages were considered.

\section{Inclusion and exclusion criteria}

Eligible studies had to fulfil the following criteria: Included studies were case reports of nephrotoxicity associated to herbs use worldwide between 2000 and 2020.

Exclusion criteria: Case reports were excluded if they involved mushrooms, poisonous plants, self-harm, excessive doses (except vitamins/minerals), drug-herbal interactions and commercial dietary supplement.

\section{Springer Open}

(-) The Author(s). 2021 Open Access This article is licensed under a Creative Commons Attribution 4.0 International License, which permits use, sharing, adaptation, distribution and reproduction in any medium or format, as long as you give appropriate credit to the original author(s) and the source, provide a link to the Creative Commons licence, and indicate if changes were made. The images or other third party material in this article are included in the article's Creative Commons licence, unless indicated otherwise in a credit line to the material. If material is not included in the article's Creative Commons licence and your intended use is not permitted by statutory regulation or exceeds the permitted use, you will need to obtain permission directly from the copyright holder. To view a copy of this licence, visit http://creativecommons.org/licenses/by/4.0/. 
Table 1 Case reports included

\begin{tabular}{|c|c|c|c|c|c|c|c|c|}
\hline Herb & Country & Gender & $\begin{array}{l}\text { Age } \\
\text { (yeas) }\end{array}$ & Reason & Preparation & Renal side effect & Causality & Reference \\
\hline $\begin{array}{l}\text { Dioscorea } \\
\text { quinqueloba }\end{array}$ & Korea & male & 52 & $\begin{array}{l}\text { cardiovascular } \\
\text { disease }\end{array}$ & Raw extract & $\begin{array}{l}\text { biopsy-proven acute } \\
\text { interstitial nephritis }\end{array}$ & Certain & 2014, [14] \\
\hline $\begin{array}{l}\text { Dioscorea } \\
\text { quinqueloba }\end{array}$ & Korea & male & 51 & $\begin{array}{l}\text { for his own } \\
\text { health }\end{array}$ & $\begin{array}{l}\text { dug up tubers of } D \text {. } \\
\text { quinqueloba and drank about } \\
400 \mathrm{~mL} \text { of juice made from } \\
\text { the raw tubers }\end{array}$ & acute kidney injury & Probable & 2015, [15] \\
\hline $\begin{array}{l}\text { Dioscorea } \\
\text { quinqueloba }\end{array}$ & Korea & male & $68-58$ & $\begin{array}{l}\text { Diabetes } \\
\text { mellitus and } \\
\text { health tonics }\end{array}$ & extract from tubers & acute kidney injury & Possible & $2011,[16]$ \\
\hline Cape aloes & $\begin{array}{l}\text { Soweto, } \\
\text { South } \\
\text { Africa }\end{array}$ & male & 47 & $\begin{array}{l}\text { to clean his } \\
\text { stomach }\end{array}$ & $\begin{array}{l}\text { Taken the remedy by mouth } \\
\text { at least three times during } \\
\text { the month before admission, } \\
\text { with the last dose about } 10 \\
\text { days before admission. }\end{array}$ & $\begin{array}{l}\text { acute oliguric renal failure } \\
\text { and liver dysfunction }\end{array}$ & Certain & $2002,[17]$ \\
\hline $\begin{array}{l}\text { Glycyrrhiza } \\
\text { glabra }\end{array}$ & Serbia & female & 39 & sterility & $\begin{array}{l}\text { ingestion of } 50-100 \mathrm{~g} \text { herbal } \\
\text { products which contained } \\
\text { licorice, every day for } 8 \text { weeks }\end{array}$ & Acute Renal Failure & Probable & 2010, [18] \\
\hline $\begin{array}{l}\text { Unknown } \\
\text { herbal vaginal } \\
\text { pessary }\end{array}$ & Nigeria & female & 22 & $\begin{array}{l}\text { To terminate } \\
\text { an unwanted } \\
\text { pregnancy }\end{array}$ & $\begin{array}{l}\text { insertion of a locally prepared } \\
\text { herb (semi-solid) into her } \\
\text { genital tract }\end{array}$ & oliguric acute kidney injury & Probable & 2017, [19] \\
\hline $\begin{array}{l}\text { Chenopodium } \\
\text { polyspermum }\end{array}$ & $\begin{array}{l}\text { Anatolia } \\
\text { region, } \\
\text { Turkey }\end{array}$ & male & 45 & $\begin{array}{l}\text { to regulate his } \\
\text { blood glucose } \\
\text { levels }\end{array}$ & & chronic renal failure & Possible & $2012,[20]$ \\
\hline Nigella sativa & Turkey & female & 62 & $\begin{array}{l}\text { antioxidant or } \\
\text { antidiabetic } \\
\text { effects }\end{array}$ & $\begin{array}{l}\text { N. sativa tablets for } 6 \mathrm{~d} \text { at } \\
\text { approximately } 2000 \text { to } 2500 \\
\text { mg/d. }\end{array}$ & acute renal failure & Possible & $2013,[21]$ \\
\hline $\begin{array}{l}\text { Tribulus } \\
\text { terrestris } \\
\text { Avena sativa } \\
\text { Panax ginseng } \\
\text { Zingiber } \\
\text { officinale }\end{array}$ & Turkey & female & 50 & $\begin{array}{l}\text { cardio- } \\
\text { protective }\end{array}$ & $\begin{array}{l}4 \text { different combination } \\
\text { herbal medicinal products } \\
\text { twice a day for } 2 \text { weeks }\end{array}$ & Acute kidney injury & Possible & 2014, [22] \\
\hline $\begin{array}{l}\text { African mango } \\
\text { (Irvingia } \\
\text { gabonensis) }\end{array}$ & Turkey & female & 42 & $\begin{array}{l}\text { slimming } \\
\text { purposes }\end{array}$ & $\begin{array}{l}\text { Three months previously she } \\
\text { started using } 2 \times 500 \mathrm{mg} \\
\text { African mango }\end{array}$ & rapid renal progression & Probable & 2015, [23] \\
\hline $\begin{array}{l}\text { Lawsonia } \\
\text { inermis }\end{array}$ & Myanmar & male & 34 & $\begin{array}{l}\text { swelling of his } \\
\text { face and } \\
\text { unhealthy } \\
\text { appearance of } \\
\text { his skin. }\end{array}$ & $\begin{array}{l}\text { boiled henna leaves, of } \\
\text { which he drank about } 700 \\
\mathrm{~mL} / \text { day for } 3 \text { days }\end{array}$ & acute kidney injury & Probable & 2017, [24] \\
\hline $\begin{array}{l}\text { Lawsonia } \\
\text { inermis L. }\end{array}$ & $\begin{array}{l}\text { Kingdom } \\
\text { of Saudi } \\
\text { Arabia }\end{array}$ & male & 32 & $\begin{array}{l}\text { chronic } \\
\text { bloating and } \\
\text { constipation }\end{array}$ & $\begin{array}{l}\text { ingestion of large } \\
\text { amounts of boiled henna }\end{array}$ & acute renal failure & Probable & $2013,[25]$ \\
\hline $\begin{array}{l}\text { Artemisia } \\
\text { herba-alba }\end{array}$ & $\begin{array}{l}\text { Tunisia } \\
\text { (North } \\
\text { Africa) }\end{array}$ & male & 59 & $\begin{array}{l}\text { antidiabetic } \\
\text { agent }\end{array}$ & $\begin{array}{l}\text { aqueous } \\
\text { extract (two cups a day for } \\
\text { two consecutive days) }\end{array}$ & acute tubular necrosis & Possible & 2010, [26] \\
\hline $\begin{array}{l}\text { Euphorbia } \\
\text { paralias }\end{array}$ & Tunisia & male & 29 & edema & $\begin{array}{l}\text { one time ingestion of boiled } \\
\text { plant of Euphorbia paralias } \\
\text { ten days before }\end{array}$ & acute renal failure & Possible & 2013, [27] \\
\hline $\begin{array}{l}\text { Cassia senna } \\
\mathrm{L} \text {. }\end{array}$ & Belgium & female & 52 & constipation & $\begin{array}{l}\text { had ingested, for }>3 \text { years, } \\
\text { one liter of an herbal tea } \\
\text { each day made from a bag } \\
\text { containing } 70 \mathrm{~g} \text { of dry senna } \\
\text { fruits }\end{array}$ & $\begin{array}{l}\text { acute hepatic failure and } \\
\text { renal impairment }\end{array}$ & Possible & 2005, [28] \\
\hline $\begin{array}{l}\text { ayurvedic } \\
\text { powder }\end{array}$ & India & male & 33 & $\begin{array}{l}\text { eczematous } \\
\text { skin lesions }\end{array}$ & $\begin{array}{l}\text { Ingesttion of ayurvedic } \\
\text { contained arsenic for last } 6 \\
\text { months }\end{array}$ & acute kidney injury & Possible & 2011, [29] \\
\hline ayurvedic & India & female & 44 & to reduce the & Contained high levels of & acute renal failure & Possible & 2015, [30] \\
\hline
\end{tabular}


Table 1 Case reports included (Continued)

\begin{tabular}{|c|c|c|c|c|c|c|c|c|}
\hline Herb & Country & Gender & $\begin{array}{l}\text { Age } \\
\text { (yeas) }\end{array}$ & Reason & Preparation & Renal side effect & Causality & Reference \\
\hline medication & & & & $\begin{array}{l}\text { side effects of } \\
\text { chemotherapy }\end{array}$ & $\begin{array}{l}\text { several heavy metals } \\
\text { including those of mercury, } \\
\text { lead, and manganese }\end{array}$ & & & \\
\hline $\begin{array}{l}\text { ayurvedic } \\
\text { supplement }\end{array}$ & India & male & 24 & $\begin{array}{l}\text { fever and } \\
\text { abdominal } \\
\text { pain }\end{array}$ & $\begin{array}{l}\text { Ingestion of Alternative } \\
\text { Medicine Containing Lead }\end{array}$ & acute kidney injury & Possible & 2019, [31] \\
\hline Carica papaya & India & male & 62 & $\begin{array}{l}\text { increase the } \\
\text { platelet count }\end{array}$ & $\begin{array}{l}\text { juice extracted from } \\
\text { papaya leaves }\end{array}$ & acute kidney injury & Possible & 2019, [32] \\
\hline $\begin{array}{l}\text { Tribulus } \\
\text { terrestris }\end{array}$ & Iran & male & 28 & $\begin{array}{l}\text { to prevent } \\
\text { kidney stone } \\
\text { formation }\end{array}$ & $\begin{array}{l}2 \mathrm{~L} \text { of } T \text {. terrestris water in two } \\
\text { consecutive days }\end{array}$ & nephrotoxicity & Probable & 2010, [33] \\
\hline $\begin{array}{l}\text { Aristolochia } \\
\text { manshuriensis }\end{array}$ & chine & male & 41 & $\begin{array}{l}\text { urinary tract } \\
\text { infection }\end{array}$ & $\begin{array}{l}4 \text { boxes (each containing } 40 \\
\text { small packets) of an herbal } \\
\text { preparation called "Fen Qing } \\
\text { Wu Lin Wan". That was taken } \\
\text { twice daily for twenty } \\
\text { consecutive days. }\end{array}$ & died in renal failure & Certain & $2010,[34]$ \\
\hline $\begin{array}{l}\text { Trigonella } \\
\text { foenum- } \\
\text { graecum }\end{array}$ & Iran & female & 62 & & $\begin{array}{l}\text { daily ingestion of heat extract } \\
\text { of fenugreek }\end{array}$ & acute interstitial nephritis & Possible & $2017,[35]$ \\
\hline $\begin{array}{l}\text { Crataegus } \\
\text { orientalis }\end{array}$ & Turkey & male & 68 & & $\begin{array}{l}\text { eating } 1 / 2 \mathrm{~kg} \text { of raw and } \\
\text { drinking five cups of tea } \\
\text { made from leaves } 3 \text { days } \\
\text { before }\end{array}$ & Acute renal failure & Possible & $2008,[36]$ \\
\hline $\begin{array}{l}\text { Tripterygium } \\
\text { wilfordii } \\
\text { HookF }\end{array}$ & $\begin{array}{l}\text { Southwest } \\
\text { china }\end{array}$ & male & 36.6 & & $\begin{array}{l}\text { ingesting approximately } 50 \mathrm{~g} \\
\text { of wild honey }\end{array}$ & $\begin{array}{l}3 \text { patients were at different } \\
\text { degrees of renal damage, and } \\
1 \text { patient with severe } \\
\text { symptoms died of acute renal } \\
\text { failure } 1 \text { day after admission }\end{array}$ & $\begin{array}{l}\text { Not } \\
\text { excluded }\end{array}$ & $2016,[37]$ \\
\hline $\begin{array}{l}\text { Colchicum } \\
\text { autumnale }\end{array}$ & Croatia & male & 62 & & $\begin{array}{l}\text { ate a salad of plant with } \\
\text { green leaves regarded as } \\
\text { wild garlic }\end{array}$ & $\begin{array}{l}\text { nephrotoxic acute tubular } \\
\text { necrosis }\end{array}$ & Possible & 2004, [38] \\
\hline $\begin{array}{l}\text { Rheum } \\
\text { rhaponticum }\end{array}$ & Germany & female & 52 & & $\begin{array}{l}\text { increased ingestion of } \\
\text { approximately } 500 \mathrm{mg} \\
\text { of rhubarb (fresh weight) per } \\
\text { day in the last } 4 \text { weeks }\end{array}$ & acute renal failure & Possible & 2012, [39] \\
\hline $\begin{array}{l}\text { Pithecellobium } \\
\text { jeringa }\end{array}$ & Malaysia & male & 45 & & & acute renal failure & $\begin{array}{l}\text { Not } \\
\text { excluded }\end{array}$ & $2007,[40]$ \\
\hline
\end{tabular}

\section{Study selection and data extraction}

Studies titles retrieved by the search were assessed for inclusion by one reviewer and a sample of excluded titles was checked by a second reviewer: no instances of discrepancy were found. Potentially relevant abstracts and full texts were assessed by two reviewers and any discrepancies resolved through discussion. Data were extracted by one reviewer and checked by a second. The causality was assessed by using Naranjo causality assessment scale [12], adapted us described in our recent publication [13].

\section{Results}

\section{Description of studies included}

The comprehensive search retrieved over 15,303 citations and 47 of them were examined in full text (Fig. 1). Eighty-five percent of the studies were excluded. As a result, 27 eligible studies were included. The key data from these reports are summarized in Table 1.

\section{Adverse effects of herbal medicines and need of phythovigilance Case reports of renal side effects associated to herbs usage worldwide}

In our search, twenty seven case reports of nephrotoxicity related to the consumption of herbs were identified around the world from Southeast Asia, Korea, South and North Africa, Turkey, Tunisia and from Belgium. The renal reactions involved mostly males $(18 / 27=66 \%)$, between 22 and 68 years old. The characteristics of cases are reported in Table 1.

Various renal syndromes were reported after the use of medicinal plants, including acute tubular necrosis, 


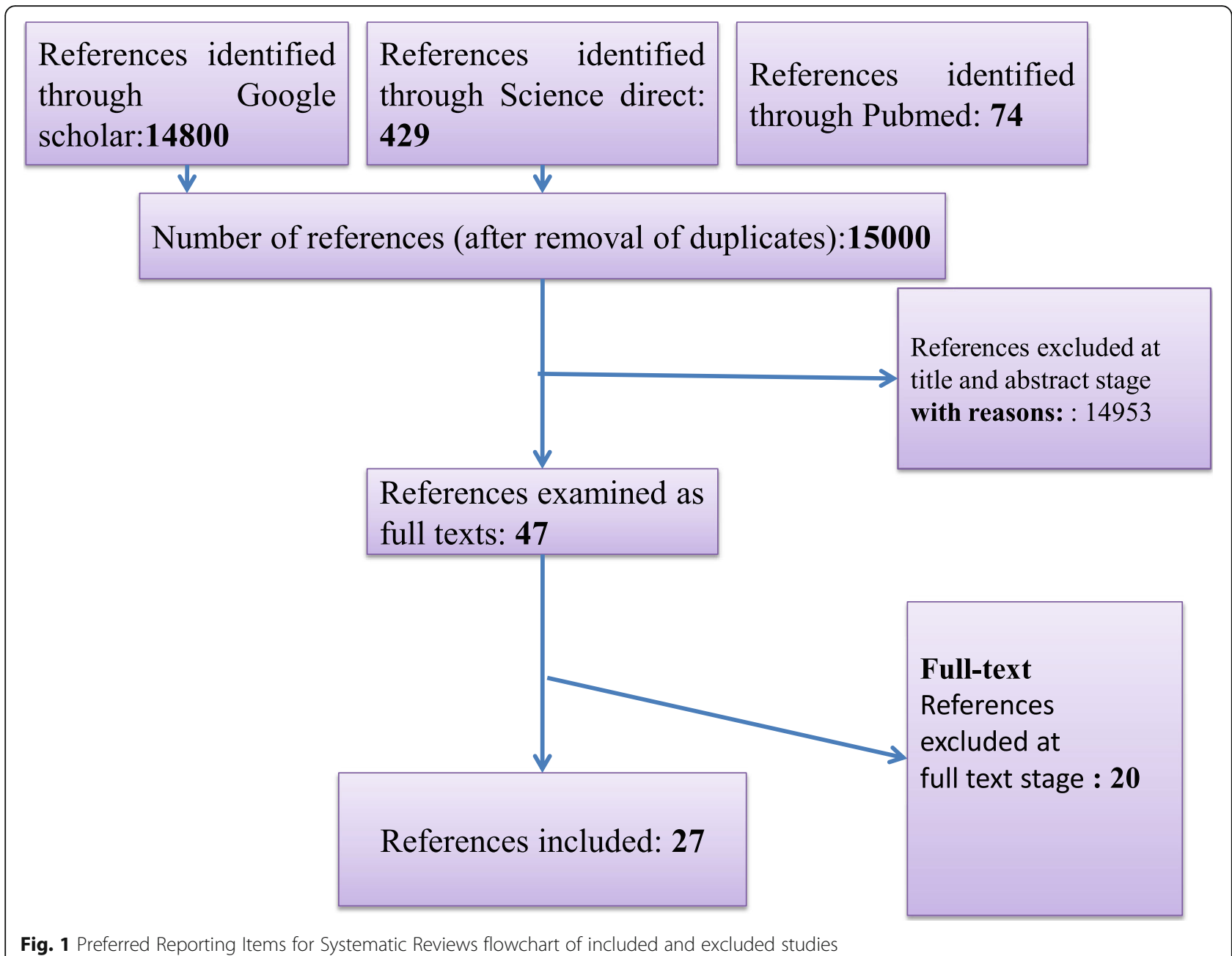

acute interstitial nephritis, acute kidney injury, and chronic renal failure.

Reports of nephrotoxicity associated with herbal medicines use encompass all forms of renal dysfunction, ranging from acute to chronic renal failure and death.

The herbal medicines most commonly associated with nephrotoxicity were: Dioscorea quinqueloba, Lawsonia inermis, Cassia senna L., Artemisia herba-alba, Chenopodium polyspermum, Cape aloes, Euphorbia paralias, Crataegus orientalis, Colchicum autumnale and Tribulus terrestris.

The causality assessment between consumption of herbal preparation and renal reaction, carried out according to Narranjo method, resulted as certain in four cases, probable in seven cases and as possible in fifteen cases. Other details on adverse reactions are described in Table 1.

\section{Why is Phytovigilance of nephrotoxic herbal medicines important in nephrology?}

A phytovigilance system needs to be established in order to assess renal adverse effects caused by herbal medicines. Many recommendations were published to dress this issue; some of them are summarized in Table 2.

\section{Discusion}

The use of traditional herbal medicine is common worldwide. Indeed, up to $80 \%$ of the population relied on herbal concoctions for their primarily health care [4], [54]. Herbal products are preferred because they are natural. In addition, they are considered "safe" and "have fewer side effects" than "synthetic drugs". On the other hand, plants contain a number of active ingredients that produce a physiological effect in the body [55]. This overview aimed to highlight nephrotoxicity of herbal medicines use in the last two decade. Even rare, reported cases of kidney side effects associated with the use of herbal medicines were very serious worldwide. Indeed we noted twenty seven case reports of nephrotoxicity related to herbal medicines. Another review found that 44 reported cases of nephrotoxicity were associated with 
Table 2 Reviews recommendations on pharmacovigilance of nephrotoxic herbal medicines

medicinal plants are associated with the pathogenesis of renal diseases in order to update healthcare practitioners to keep abreast with

Some evidence was in line with the potential nephrotoxicity of plants and their reformers. Despite the lack of clinical research for evaluation of their renal damage, the herbs may be focused in term of their nephrotoxicity; and there is a need for further studies on the scientific basis of their nephrotoxicity

Strict controls on the presence of adulterants within herbal medicines, labeling of dosages and contraindications, and manufacturing techniques must be maintained to ensure the safety of those consuming herbal medicines.

Clinicians should consider herbal medicine use in patients with unexplained acute kidney injury or progressive chronique kidney disease. In addition, exposure to herbal medicine containing aristolochic acid may increase risk for future uroepithelial cancers, and patients require appropriate postexposure screening

it is important that alternative medicines not be demonized as a whole, but that their use and consequences be closely observed and reported to build a more comprehensive understanding of their impact in our clinical practice and to foster research on the potential harm or, in some cases, possible benefits

Considering the complexity of the toxic components and the diversity of their acting pathway, a lot of work needs to do on pharmacovigilance, "Omics" technologies, and administration of mixtures alleviating toxicities. Pharmacovigilance methods can be used for monitoring kidney toxicity traditional Chinese medicines safety. "Omics" technologies have the potential for the development of molecular markers hopefully allowing for detection of early changes in toxic kidney injury with high sensitivity and specificity. These researches may help us to deeply learn the mechanism of traditional Chinese medicines renal toxicity at the molecular and gene level

Use of modern cell biological, biochemical, in vitro and in vivo techniques for the evaluation of medicinal plants safety is needed

Herbal medicines related to either severe or moderate adverse events supported by a case report should be avoided.

Cooperation between orthodox physicians and traditional practitioners is needed to bring together the full case details. Independent scientific assistance on toxicological investigation, botanical verification can be invaluable for full evaluation of any case report. Systematic pharmacovigilance is essential to build up reliable information on the safety of herbal medicines for the development of appropriate guidelines for safe effective use

It is deemed necessary that a basic knowledge of the pharmacological aspects of phytotherapy be included in the regular Course of Medicine.

Phytovigilance: A medical requirement and a legal obligation

Need to incorporate pharmacovigilance of herbal medicine to the curriculum

There is a need for herbal medicine regulation, technical and training assistance, and funding as being major challenges to HM pharmacovigilance in countries. Particular attention to the development of pharma- covigilance of herbal medicine is required in Africa.

The use of indigenous drugs, herbal medicine and traditional materiamedica can only be understood through a combination of historical, ecological, economic, cognitive, and pharmacolog- ical approaches, while anecdotal references are lost in space and time.

A demonstration of the safety of herbal medicines for registration purposes should include at least in vitro and in vivo genotoxicity assays, long-term rodent carcinogenicity tests (for drugs intended to be continuously used for $>3$ months or intermittently for $>6$ months), reproductive and developmental toxicity studies (for drugs used by women of childbearing age), and investigation of the effects on drug-metabolizing enzymes.

herbal or dietary supplements worldwide [48]. Nephrotoxic herbs most reported were:

\section{Lawsonia inermis}

Henna is a traditional cosmetic agent and is used worldwide, not only as a cosmetic agent but also is applied to the body on lesions in the treatment of seborrheic dermatitis or fungal infections. Different pathologies have been described as caused by henna. For this reason people should be informed about the side-effects of topical henna application and clinicians should be aware of these manifestations [56]. Lawsone (2-hydroxy-1,4 naphthoquinone) is a chemical agent present in henna [4-6]. It has been shown to cause severe haemolytic anaemia and renal tubular necrosis in animals [56]. Most reports of henna toxicity have been attributed to adding a synthetic dye para-phenylenediamine (PPD). Indeed unreliable quality can be a problem. In particular, this poses a risk when herbal medicines are contaminated (e.g. with heavy metals) or adulterated (e.g. with prescription drugs) [57]. Another example for herbs contamination nephrotoxicity was ayurvedic supplement from India, which contained high levels of several heavy metals including those of mercury, lead, arsenic and manganese. In fact, previous overview reported that herbal medicinal products were adulterated or contaminated with dust, pollens, insects, rodents, parasites, microbes, fungi, mould, toxins, pesticides, toxic heavy metals and/or prescription drugs. The most severe adverse effects caused by these adulterations were agranulocytosis, meningitis, multi-organ failure, perinatal stroke, arsenic, lead or mercury poisoning, malignancies 
or carcinomas, hepatic encephalopathy, hepatorenal syndrome, nephrotoxicity, rhabdomyolysis, metabolic acidosis, renal or liver failure, cerebral edema, coma, intracerebral haemorrhage, and death. Adulteration and contamination of herbal medicinal products were most commonly noted for traditional Indian and Chinese remedies, respectively [58].

Cassia acutifolia and angustifolia plants are widely used as laxatives. The mechanism of renal injury remains debatable. Massive loss of fluid and electrolytes during laxative abuse may cause renal dysfunction. Moreover, a direct cytotoxic effect on the tubular cells may also be involved, as it has been shown that anthraquinone derivatives may be accumulated in the kidneys [59], [60].

Crataegus spp. (hawthorn) monopreparations are predominantly used for treating congestive heart failure. Data from the literature indicated that hawthorn is rarely associated with serious adverse events. However, the unsupervised use of this drug can be associated with problems, especially if given with concomitant medications [61].

Artemisia herba-alba, Artemisia herba-alba Asso (Asteraceae) essential oil contained in majority: cischrysanthenyl acetate (25.12\%); (2E,3Z) 3,5-heptadienal2-ethyliden-6-methyl (8.39\%); $\alpha$-thujone (7.85\%); myrtenyl acetate (7.39\%); verbenone (7.19\%), chrysanthenone (4.98\%) [62].

\section{Cape aloes}

The Aloe plant is employed as a dietary supplement in a variety of foods and as an ingredient in cosmetic products. The widespread human exposure and its potential toxic and carcinogenic activities raise safety concerns. Chemical analysis revealed that the Aloe plant contained various polysaccharides and phenolic chemicals, notably anthraquinones [63]. Ingestion of Aloe preparations is associated with diarrhea, hypokalemia, pseudomelanosis coli, kidney failure, as well as phototoxicity and hypersensitive reactions [63].

\section{Dioscorea quinqueloba}

belonging to the family Dioscoreaceae, the most important identified compound from Dioscorea species is diosgenin [64].

From the most reported renal adverse effect we noted acute interstitielle nephritis and acute kidney injury; which is similar with other study [13].

Tripterygium wilfordii's nephrotoxic power is well known. According to a recent systematic review and meta-analysis on its nephrotoxicity, the incidence rate of nephrotoxicity in Tripterygium wilfordii Hook. F preparations was 5.81\% [65]. A single case report of Tripterygium wilfordii hook F's renal and cardiac toxicity in a 36-yr-old man has been reported. Three days after ingesting thunder god vine extract, the patient presented with profuse nausea, vomiting, diarrhea, leukopenia, renal failure, hypotension, and extensive cardiac abnormalities. The patient died $3 \mathrm{~d}$ after presentation from intractable shock. The authors could not differentiate the cause of this patient's renal dysfunction, postulating that it could have been supplement-induced nephrotoxicity, in conjunction with prolonged shock [66].

Colchicum autumnale is an herbaceous plant in the liliaceae family. Accidental poisonings by this plant generally result from a botanical confusion, with other edible herbaceous liliaceae; wild leek (Allium polyanthum) or wild garlic (Allium ursinum). This confirms that a simple confusion when identifying a plant deemed edible can have particularly deleterious consequences for patients [67].

\section{Aristolochia manshuriensis}

Chinese herbal medicine has been practiced for the prevention, treatment, and cure of diseases for thousands of years. Some of the nephrotoxic components from herbs are aristolochic acids and other plant alkaloids [44]. A recent review has listed case reports of nephrotoxicity due to Chinese herb species containing aristolochic acid [68]. The kidney manifestations of nephrotoxicity associated with Chinese herbal medicine included acute kidney injury, CKD, nephrolithiasis, rhabdomyolysis, Fanconi syndrome, and urothelial carcinoma [44].

Glycyrrhiza glabra (licorice) Natural licorice is extracted from Glycyrrhiza glabra root containing glycyrrhizin or glycyrrhizic acid in sufficient quantities it affects blood pressure and causes other health issues. Licorice has been involved in the renal disease by inhibiting major renal transport processes needed for filtration, secretion, and absorption [69]. Hence, licorice should be carefully monitored for its use in patients with renal problems [70].

However, we observed the absence of some much known nephrotoxic plants in the two last decade, it is notably Ephedra species [71], Tripterygium wilfordii hook $\mathrm{F}$ [66]. What shows some phytovigilance that needs to be more increased.

Several reviews have listed a list of nephrotoxic plants and have proposed several recommendations concerning the fight against this use [72], [70]. Which shows the interest of creating a pharmacovigilance system for these plants particularly for nephrology.

The potential of natural products to cause renal dysfunction is justifiable. It is imperative that the use of natural products be closely monitored in all patients. Healthcare professionals should take an active role in identifying patients using natural products and providing 
appropriate patient education [72]. Indeed we summarized some published recommendations in this way.

Herbal medicine uses medicinal plants prepared by means of adapted extracting technologies and appropriate pharmacological preparations, purified and standardized in their chemical principles. As with any form of therapy, there are possible side effects, contraindications, pharmacological interactions. It is considered necessary that a basic knowledge of the pharmacological aspects of herbal medicine be included in the regular course of medicine [49]. Plant extracts can have kidney toxicity due to their inherent properties. If they exhibit some degree of toxicity, the risks can be weighed against the benefits and decisions can be made regarding their continued availability, in a manner similar to that currently done for nephrotoxic pharmaceutical agents. Importantly, the inherent properties of the herb are not the only source of kidney problems associated with plants, as plant-drug interactions, errors in dosing and identification, and contaminants in the mixture are all of concern.. Strict controls on the presence of adulterants in herbal medicines, labeling of dosages and contraindications and manufacturing techniques must be maintained to ensure the safety of consumers of medicinal plants [73].

\section{Conclusion}

Herbal medicine seemed to present a real risk for the kidney. Case reports from the literature have clearly shown the association between the use of herbs and the occurrence of nephrotoxicity worldwide. Hence the need to incorporate a phythovigilance system in the nephrology service, especially in Africa and Asia.

\section{Acknowledgements}

Not applicable.

\section{Ethics approval and consent}

Not applicable.

\section{Authors' contributions}

Noufissa Touiti, Sanae Achour and Tarik Sqalli Houssaini analyzed Studies titles for inclusion and contributed in the writing of the manuscript. Noufissa Touiti, supervising the whole work. All authors read and approved the final manuscript.

\section{Availability of data and materials}

Not applicable.

\section{Competing interests}

The authors declare that they have no competing interests.

\section{Author details}

${ }^{1}$ Laboratory of Biomedical and Translational Research, Faculty of Medicine and Pharmacy of Fez, Sidi Mohammed Ben Abdellah University, Fez, Morocco. ${ }^{2}$ Faculty of Science and Technology of Fes, Sidi Mohammed Ben Abdellah University, Fez, Morocco. ${ }^{3}$ Research Team Kidney Laboratory of Molecular Bases in Human Pathology and Therapeutic Tools, University Hospital Center Hassan II, Fez, Morocco. ${ }^{4}$ Laboratory of Toxicology, University Hospital Center Hassan II, Fez, Morocco. ${ }^{5}$ Faculty of Medicine and Pharmacy of Fez, Fez, Morocco.
Received: 15 June 2020 Accepted: 11 January 2021

Published online: 19 January 2021

\section{References}

1. Touiti N, Sqalli T, Iken I, Benslimane A, Achour S. Prevalence of herbal medicine use among patients with kidney disease : a cross-sectional study from Morocco. Néphrologie \& Thérapeutique. 2020:16(1):43-9.

2. Kara B. Herbal product use in a sample of Turkish patients undergoing haemodialysis. J Clin Nurs. 2009;18:2197-205.

3. Lai M-N, Lai J-N, Chen P-C, Hsieh S-C, Hu F-C, Wang J-D. Risks of kidney failure associated with consumption of herbal products containing mu Tong or Fangchi: a population-based case-control stud. Am J Kidney Dis. 2010;55(3):507-18.

4. Corinne Isnard Bagnis, MD, PhD, Gilbert Deray, Alain Baumelou, MD, Moglie Le Quintrec, MD, and Jean Louis Vanherweghem M. Herbs and the kidney. Am J Kidney Dis 2004;44(1):1-11.

5. Awodele O, Daniel A, Popoola TD, Salami EF. A study on pharmacovigilance of herbal medicines in Lagos west Senatorial District, Nigeria. Int J Risk Saf Med. 2013;25(4):205-17.

6. Skalli S, Bencheikh RS. Pharmacovigilance of herbal medicines in Africa : questionnaire study. J Ethnopharmacol. 2015;171:99-108.

7. Debbie S, Graeme L, Pierre D, Elizabeth W, Kelvin C. Pharmacovigilance of herbal medicine. J Ethnopharmacol. 2012;140(3):513-8.

8. Lehmann $\mathrm{H}$, Pabst J. La phytovigilance : impératif médical et obligation légale. Ann Pharm Fr. 2015:1-12.

9. Barnes J. Pharmacovigilance of Herbal Medicines A UK Perspective. Drug Sade. 2003;26:12.

10. WHO. guidelines on safety monitoring of herbal medicines in pharmacovigilance systems. World Health Organization, Geneva. 2004.

11. Skalli S, David J, Palmer G. Botanicus et Phytotox : base de données de toxicologie végétale. Intérêt en toxicologie d ' urgence et en phytovigilance. Therapie. 2006;61(2):133-7.

12. C. A. Naranjo, U. Busto, Pharm.D., E. M. Sellers, M.D., Ph.D., P. Sandor, M.D., I. Ruiz, Pharm.D., E. A. Roberts, M.D., E. Janecek, B.Sc. Phm., C. Domecq, Pharm. D.,and D. J. Greenblatt. A method for estimating the probability of adverse drug reactions. Clin Pharmacol Ther 1981;30(2):239-245.

13. Touiti N, Achour S, Iken I, Chebaibi M, Houssaini TS. Nephrotoxicity associated with herbal medicine use, experience from Morroco. Toxicol Anal Clin. 2019:31(3):145-52.

14. Kim HY, Kim SS, Bae SH, Bae EH, Ma SK, Kim SW. Acute interstitial nephritis induced by Dioscorea quinqueloba. BMC Nephrol. 2014;15(1):1-5.

15. Kang K, Heo ST. A case of life-threatening acute kidney injury with toxic encephalopathy caused by Dioscorea quinqueloba. Yonsei Med J. 2015; 56(1):304-6.

16. Kim CS, Kim SM, Choi JS, Bae EH, Kim SW. Dioscorea Quinqueloba induces acute kidney injury : two case reports. J Clin Toxicol. 2011;1(2):5-6.

17. Luyckx VA, Ballantine R, Claeys M, Cuyckens F, Van Den Heuvel H, Cimanga RK, et al. Herbal remedy-associated acute renal failure secondary to cape aloes. Am J Kidney Dis. 2002;39(3):1-5.

18. Velickovic-radovanovic RM, Kitic D, Kostic S, Cvetkovic T, Djordjevic V. Acute renal failure after Licorice ingestion : a case report. Cent Eur J Med Acute. 2010:6(1):113-6.

19. Adejumo OA, Akinbodewa AA, Ogunleye A, Agoi OF, Abolarin OS. A case report of acute kidney injury following the use of herbal vaginal Pessary. African J Med Heal Sci. 2017;16:65-7.

20. Acık DY, Yilmaz M, Sahin HH, Sayıner Z, Koruk I, Tiryaki O, et al. Case report Management of Chenopodium polyspermum toxicity with plasma exchange and Hemodialysis. J Clin Apher. 2012;27(5):278-81.

21. Arslan E, Sayın S, Demirbaş \$̧, Çakar M, Somak NG. A case study report of acute renal failure associated with Nigella sativa in a diabetic patient. J Integr Med. 2013;11(1):64-6.

22. Ok ES, Hastanesi K, Tatar E, Tosun A. Acute kidney injury induced by herbal products : a case report. Turk Neph Dial Transpl. 2014;23(3):256-8.

23. Özkan G, Ulusoy Ş. A case of renal failure developing in association with African mango consumption. Int J Clin Exp Med. 2015:8(4):6374-8.

24. Khine YY. Acute kidney injury following ingestion of henna leaf extract : a case report from Myanmar. Blood Purif. 2017:44(suppl 1):41-5.

25. Qurashi HEA, Qumqumji AAA, Zacharia Y. Acute renal failure and intravascular Hemolysis following henna ingestion. Saudi J Kidney Dis Transplant. 2013;24(3):553-6. 
26. Aloui S, Skhiri H, Ltaief A, Elmay M. An exceptional case of acute renal failure : is there a renal toxicity of Artemisia herba-alba ? Ren Fail. 2010;32: 1009-11.

27. Boubaker K, Ounissi M, Brahmi N, Goucha R, Hedri H, Ben T. Acute renal failure by ingestion of Euphorbia paralias. Saudi J Kidney Dis Transplant. 2013:24(3):571-5.

28. Vanderperren B, Rizzo M, Angenot L, Haufroid V, Jadoul M, Hantson P. Acute liver failure with renal impairment related to the abuse of Senna Anthraquinone glycosides. Ann Pharmacother. 2005;39(May 2014):1353-7.

29. Jamale TE, Edward K, Hospital M, Hase N, Edward K, Hospital M. Acute kidney injury due to arsenic contained in alternative medicines in the setting of adult Nephrotic syndrome acute. J Clin Toxicol. 2011;1(1):1-2.

30. Gulia S, Gota V, Kumar SD, Gupta S. Acute renal failure secondary to ingestion of alternative medication in a patient with breast cancer. J Cancer Res Ther. 2015;11:1006-8.

31. Moorthy S, Samuel AE, Moideen F, Peringat J. Interstitial nephritis presenting as acute kidney injury following ingestion of alternative medicine containing Lead : a case report. Adv J Emerg Med. 2019;3(1):8-10.

32. Raja VA, Bhargav KM, Kumar BS, Narayanamurthy D, Bhattaram S. Acute kidney injury, oral mucositis and gastritis as complications of ingestion of papaya leaf juice extract in a patient presenting with dengue fever. J Clin Sci Res. 2019:8:204-6.

33. Talasaz AH, Abbasi M, Abkhiz S, Dashti-khavidaki S. Tribulus terrestris -induced severe nephrotoxicity in a young healthy male. Nephrol Dial Transpl. 2010;25(July):3792-3.

34. Shaohua Z, Ananda S, Ruxia Y, Liang R, Xiaorui C, Liang L. Fatal renal failure due to the Chinese herb "' GuanMu Tong "' ( Aristolochia manshuriensis ): autopsy findings and review of literature. Forensic Sci Int. 2010;199(1-3):e5-7.

35. Zununi-vahed S, Ardalan M, Mahmoodpoor F, Ardalan K. Fenugreek (Trigonella foenum-graecum) induced interstitial nephritis. J Ren Inj Prev. 2017:6(4):286-8

36. Horoz M, Genctoy G, Ozcan IT, Kiykim A. Crataegus Orientalis associated multiorgan hypersensitivity reaction and acute renal failure. Intern Med. 2008:47(August 2016):2039-42.

37. Zhang Q, Chen X, Chen S, Liu Z, Wan R. Fatal honey poisoning caused by Tripterygium wilfordii hook $F$ in Southwest China : a case series. Wilderness Environ Med. 2016;27(2):271-3.

38. Sundov Z, Nincevic Z, Definis-gojanovic M. Fatal colchicine poisoning by accidental ingestion of meadow saffron-case report. Forensic Sci Int. 2005; 149:253-6.

39. Albersmeyer M, Hilge R, Schröttle A, Weiss M, Sitter T, Vielhauer V. Acute kidney injury after ingestion of rhubarb : secondary oxalate nephropathy in a patient with type 1 diabetes. BMC Nephrol. 2012;13:141.

40. Wong JS, Ong T, Chua $\mathrm{H}$, Tan C. Acute Anuric renal failure following Jering bean ingestion. Asian J Surg. 2007;30(1):80-1.

41. Liwa AC, Jaka HM. Renal diseases and use of medicinal herbal extracts : a concise update of reported literature in Africa. J Nephrol Ren Ther. 2016;2.

42. Kolangi F, Memariani Z, Bozorgi M, Mozaffarpur SA, Mirzapour M. Herbs with potential nephrotoxic effects according to the traditional Persian medicine : review and assessment of scientific evidence. Curr Drug Metab. 2018;19(7): $1-10$.

43. Mohammad A. A brief study of toxic effects of some medicinal herbs on kidney. Adv Biomed Res. 2012;1:3.

44. Yang B, Xie Y, Guo M, Rosner MH, Yang H, Ronco C. Nephrotoxicity and Chinese herbal medicine. Clin J Am Soc Nephrol. 2018;13:1605-11.

45. Luyckx VA. Nephrotoxicity of alternative medicine practice. Adv Chronic Kidney Dis [Internet]. 2012;19(3):129-41.

46. $X u X$, Yang $L$, Jiang J. Renal toxic ingredients and their toxicology from traditional Chinese medicine. Expert Opin Drug Metab Toxicol. 2016; 5255(December 2015):1-30.

47. Saad B, Azaizeh H, Abu-hijleh G, Said O. Safety of traditional Arab herbal medicine. eCAM. 2006;3(September):433-9.

48. Tangkiatkumjai M. Existing evidence for safe use of herbal medicines in chronic kidney disease. Int J Pharm Pharm Sci. 2015;7(9):30-4.

49. Firenzuoli F, Gori L, Neri D. Fitoterapia clinica : opportunità e problematiche. Ann Ist Super Sanità. 2005;41(1):27-33.

50. Mag H. Need to incorporate pharmacovigilance of herbal medicine to the curriculum. Natl J Physiol Pharm Pharmacol. 2014;4(2):99-100.

51. Leonti M, Casu L. Traditional medicines and globalization : current and future perspectives in ethnopharmacology. Front Pharmacol. 2013;4(July):1-13.
52. Moreira DDL, Teixeira SS, Monteiro MHD, De-oliveira ACAX, Paumgartten FJR. Traditional use and safety of herbal medicines. Rev Bras Farmacogn. 2014;24:248-57.

53. Zhang J, Wider B, Shang H, Li X, Ernst E. Quality of herbal medicines : challenges and solutions. Complement Ther Med. 2012;20(1-2):100-6.

54. Tchacondo T, Karou SD, Batawila K, Agban A, Ouro-bang K, Anani KT, et al. Herbal remedies and their adverse effects in tem tribe traditional medicine in TOGO. Afr J Tradit Complement Altern Med. 2011;8(1):45-60.

55. Zerrin TH. Pharmacovigilance of herbal medicine : Herbavigilance. Adv Pharmacoepidemiol Drug Saf. 2016;5(4):4

56. KOK AN, ERTEKIN MV, V. ERTEKIN BA. Henna ( Lawsonia inermis Linn ) induced haemolytic anaemia in siblings. Int J Clin Pr. 2004;58(5):530-2.

57. Ernst E. Risks of herbal medicinal products. Pharmacoepidemiol Drug Saf. 2004;13(November 2003):767-71.

58. Posadzki P, Watson L, Ernst E. Contamination and adulteration of herbal medicinal products ( HMPs ): an overview of systematic reviews. Eur J Clin Pharmacol. 2013;69:295-307.

59. Vashishtha VM, John TJ, Kumar A. Clinical \& pathological features of acute toxicity due to Cassia occidentalis in vertebrates. Indian J Med Res. 2009; 130(July):23-30.

60. Ulbricht C, Conquer J, Costa D, Higdon ERB, Isaac R, Rychlik I, et al. An evidence-based systematic review of Senna ( Cassia senna ) by the natural standard research. J of Dietary Suppl. 2011;8(2):189-238.

61. Daniele C, Mazzanti G, Pittler MH, Ernst E. Adverse-event profile of Crataegus Spp. A Systematic Review Drug Saf. 2006;29(6):523-35.

62. Bezza L, Mannarino A, Fattarsi K, Mikail C, Abou L, Kaloustian J. Composition chimique de l'huile essentielle d'Artemisia herba-alba provenant de la région de Biskra (Algérie). Phytothérapie. 2010;8:277-81.

63. Guo X, Mei N. Aloe Vera - A Review of Toxicity and Adverse Clinical Effects. $J$ Environ Sci Heal Part C. 2016;(March):1-42.

64. Kumar S, Das G, Shin H, Patra JK. Dioscorea spp. (a wild edible tuber): a study on its Ethnopharmacological potential and traditional use by the local people of Similipal biosphere reserve, India. Front Pharmacol. 2017; 8(February):1-17.

65. Feng X, Fang S-N, Liang N, Liu J-P, Chen W. Nephrotoxicity of Tripterygium wilfordii hook. F preparations: a systematic review and meta-analysis. J Altern Complement Med. 2018:00(00):1-16.

66. Chou W-C, Wu C-C, Yang P-C, Lee Y-T. Hypovolemic shock and mortality after ingestion of Tripterygium wilfordii hook F : a case report. Int J Cardiol. 1995;49:173-7.

67. Boulamery A, Torrents R, Simon N, De Haro L. Intoxication aux colchiques : à propos d' un cas collectif dans le Sud de la France. Toxicol Anal Clin. 2017; 29(July 2019):348-9.

68. Christine A. Kidney toxicity related to herbs and dietary supplements : Online table of case reports. Part 3 of 5 series. Food Chem Toxicol 2017;107: 502-519.

69. Allard T, Wenner T, Greten HJ, Efferth T. Mechanisms of herb-induced nephrotoxicity. Curr Med Chem. 2013:20:2812-9.

70. Mariyam N, Ezhilarasan D. Pharmacovigilance of the herbal medicines use : a review on case reports Abstract. J Afrikana. 2016;3(4):294-303.

71. Powell T, Hsu FF, Turk J, Hruska K. Ma-Huang Strikes Again: Ephedrine Nephrolithiasis. AmericanJournalofKidneyDiseases. 1998;32(1):153-9.

72. Nauffal M, Gabardi S. Nephrotoxicity of natural products. Blood Purif. 2016; 41:123-9.

73. Wojcikowski KEN, Johnson DW, Gobé G. Medicinal herbal extracts - renal friend or foe ? Part one : The toxicities of medicinal herbs. Nephrol 2004; 2004;9(July):313-8.

\section{Publisher's Note}

Springer Nature remains neutral with regard to jurisdictional claims in published maps and institutional affiliations. 